ANNA SZYLAR* - TARNOBRZEG

\title{
BUSKO W ŚWIETLE OPISU WIZYTACJI BISKUPA MICHAŁA JERZEGO PONIATOWSKIEGO Z ROKU 1782
}

W archiwum sióstr Norbertanek w Imbramowicach zachowała się rękopiśmienna księga zatytułowana Akt wizyty generalney z rozkazu Jaśnie Oświeconego Xiązęcia Jmci Michata Jerzego Ciołka Poniatowskiego [...] $]^{1}$.

Jest to wolumin liczący 130 stron, stanowiący niezwykle cenne źródło do dziejów konwentu norbertanek oraz miasta Buska przede wszystkim w XVIII wieku. Podaje bowiem dokładne informacje z następujących obszarów: Stan fary i kościota buskiego (s. 5-51), Summariusz praw i dokumentów fundacyi kościoła farnego oraz y klasztornego WW. PP. Norbertanek w Busku (s. 52- 66), Stan ekonomiczny i dochodowy kościoła i klasztoru buskiego (s. 67-97), Stan osobisty duchowieństwa kościoła farnego w Busku (s. 98- 99), Stan osobisty WW. Panien Zakonnych Świętego O. Norberta klasztoru buskiego (s. 100-103), Panny świeckie (s. 104), Stużba klasztorna (s.105), Rozporzadzenie czasu życia zakonnego (s. 106-108), Dekret generalny o kościele (s. 108-111), O zakonności (s. 111-114), O szkole i szpitalu (s. 114-116), O mieście (s. 117-123), O dobrach i pożytkach (s. 123-166), O kasie klasztornej (s. 127-129) i O kondycyach trzechletnich (s. 129-130).

Dane powyższe są tym cenniejsze, iż nie zachowały się księgi miejskie Buska. Dotychczas na temat miasta i klasztoru norbertanek ukazało wprawdzie kilka ujęć

* Anna Szylar - dr historii, starszy wykładowca w Państwowej Wyższej Szkole Zawodowej im. prof. Stanisława Tarnowskiego w Tarnobrzegu.

${ }^{1}$ Archiwum Norbertanek w Imbramowicach (dalej ANI), rps G 6, Akt wizyty generalney generalney z rozkazu Jaśnie Oświeconego Xiążęcia Jmci Michała Jerzego Ciołka Poniatowskiego z Bożey i Stolicy Apostolskiey łaski biskupa płockiego, xiążęcia pułtuskiego, koadjutora z całą jurysdykcyą krakowskiego, xiążęcia siewierskiego, opata kommendataryusza czerwińskiego, diakona warszawskiego, orderów Orła Białego y Świętego Stanisława Kawalera, za kommisarstwa wielmożnego Jmci xiędza Franciszka Ossowskiego, kustosza krakowskiego, za rządów nayprzewielebnieyszy Jeymci Panny Konstancyi Kochanowski, klasztoru buskiego Zakonu ś. Norberta xieni, przez wielmożnego Jmci xiędza Franciszka Dunina z Ciekanowa Kozickiego, kollegiaty pileckiey dziekana, wizytatora delegowanego odprawioney, w roku Pańskim [1782, 4 XII], dalej (G 6). Opis wizytacji został zmikrofilmowany i znajduje się w Ośrodku ABMK w Lublinie, sygn. 4119. 
pióra Romana Grodeckiego ${ }^{2}$, Feliksa Kiryka ${ }^{3}$, Zenona Guldona i Lecha Stępkowskiego $^{4}$, Jana Wiśniewskiego ${ }^{5}$ i Eugeniusza Wiśniowskiego ${ }^{6}$, ale żadne nie obejmowało dziejów miasta w końcu XVIII wieku.

Jakkolwiek niniejszy szkic nie wyczerpuje także problematyki miejskiej w tym czasie, to jednak przynosi nowe informacje i ustalenia.

W II połowie XVIII wieku Busko należało do powiatu wiślickiego, który stanowił część województwa sandomierskiego. Najbliżej mieszkańcy mieli do stolicy powiatu - Wiślicy, bo zaledwie 2 mile. Aby dotrzeć do Kielc należało pokonać odległość sześciu mil, natomiast z Buska do Sandomierza i Krakowa była taka sama droga, wynosząca po 10 mil w jedną i drugą stronę.

Busko było od końca XII wieku własnością konwentu norbertanek. Jeszcze przed sprowadzeniem zakonnic istniał w osadzie kościół z obrazem Matki Boskiej, który po fundacji klasztoru wraz z uposażeniem został włączony do ich posiadłości i służył zarówno norbertankom jak i mieszkańcom Buska oraz okolicznych wsi ${ }^{7}$. Do fary buskiej należała bowiem w 1782 roku ludność miasta i 14 osad. Okręg parafialny tworzyły: Nadole leżące pod miastem, Łagiewniki, Zbludowaniec, Kowalczyce i Biniątki, położone w odległości mniejszej niż ćwierć mili od Buska.Ponadto pełne ćwierć mili było do świątyni ze Zbrodzic, Bronin i Owczar, powyżej mili było z wiosek Wolica, Chotelek Zielony, Waluz, Kostki Duże a trzy ćwierci mili z Kostek Małych. W przypadku wsi Radzanów dwór, kilka chałup z młynem i browarem przypisanych było do fary w Busku a pozostała, większa część ,za woda" do kościoła w Dobrowodzie ${ }^{8}$.

Ludność fary w 1781 roku wynosiła 2900 osób, z czego do spowiedzi wielkanocnej przystąpiło 2350 osób uprawnionych (81\%). Tak więc kościół parafialny w Busku należał do grupy o znacznej liczbie parafian. Warto również przytoczyć dane $\mathrm{z}$ tego samego roku na temat innych udzielanych sakramentów, były to 43 śluby i 173 chrzty. Liczba zmarłych parafian wyniosła 142 osoby, co stanowiło 82 $\% \mathrm{w}$ stosunku do narodzonych dzieci.

${ }^{2}$ R. Grodecki, Dzieje klasztoru premonstratensów w Busku w wiekach średnich, „Rozprawy Akademii Umiejętności, Whf", 191, t. 57.

${ }^{3}$ F. Kiryk, Dzieje Buska w XII - XVI wieku, „Studia Kieleckie”, $3 / 47$ (1985) s. 7- 24; F. Kiryk, Urbanizacja Małopolski. Województwo Sandomierskie XIII-XVI w., Kielce 1994, s. 29-31.

${ }^{4}$ Z. Guldon, L. Stępkowski, Busko na tle miast powiatu wiślickiego od połowy XVII do końca XVIII w., ,Studia Kieleckie”, 3/47 (1985) s. 25- 35.

5 J. Wiśniewski, Historyczny opis kościołów, miast, zabytków i pamiątek w stopnickim, Mariówka 1929 (reprint 2000), s. 29-41.

${ }^{6}$ E. Wiśniowski, Prepozytura wiślicka do schyłku XVIII wieku. Materiały do struktury organizacyjnej, Lublin 1976, s. 35-39.

${ }^{7}$ Por. Kiryk, Dzieje Buska, s. 9-10, 21; E. Wiśniowski, Rozwój sieci parafialnej w prepozyturze wiślickiej w średniowieczu, Warszawa 1965, s. 67; Grodecki, Dzieje klasztoru, s. 13;

${ }^{8}$ ANI, G 6, s. 5. W II połowie XV w. do parafii należały: Busko miasto i Busko wieś oraz Biniątki, Branina, Chotel Zielony, Radzynów - folwark, Siesławice, Wełcz, Wola Siesławska, Zbludowice, Zbrodzice, Krawczyce, Kostki Wielkie, Kostki Małe, Łagiewniki, Nadolin. 
Podkreślić należy, że z racji przynależności miasta do konwentu norbertanek, podobnie jak we wcześniejszych okresach, również i w XVIII wieku zamieszkiwali w nim tylko katolicy. Starozakonnych można było spotkać jedynie sporadycznie w osadach okręgu parafialnego ,dusz innej religij w tej farze nie masz, oprócz Żydów po browarach i karczmach".

Jedynymi murowanymi budowlami w mieście, wymienionymi w protokole powizytacyjnym, były kościół parafialny i klasztor. Podróżujący w tym czasie po Polsce J. F. Carosi wzmiankując na temat Buska pisał: „Budynek klasztorny wraz z kościołem, który jest jednocześnie kościołem parafialnym miasta, jest murowany; prócz tych budowli występują jeszcze dwa murowane budynki mieszczańskie, częściowo jednakże również drewniane"10.

Busko nie posiadało w tym czasie również ratusza, co wytknął właścicielkom miasta wizytator, nakazując jego wybudowanie „w pośrodku miasta w czasie sposobnym [...] w tym osobną izbę do sądzenia na dole lub górze"11. Koszty budowy miały ponieść w całości norbertanki, ale już utrzymanie ratusza należało do mieszczan. Ponadto mieszkańcy powinni wybudować za własne pieniądze więzienie i utrzymywać je z dochodów miejskich ${ }^{12}$.

Wydaje się, że zalecenie wizytatora w sprawie budowy ratusza było zrealizowane, ponieważ po pożarach, które nawiedziły Busko w latach 1819, 1820 i 1821, podczas porządkowania miasteczka rozebrano stary, drewniany ratusz, który był na tyle zniszczony, że groził zawaleniem ${ }^{13}$.

Zabudowa miejska była skoncentrowana wokół kwadratowego rynku, dwóch głównych i kilku drobnych bocznych ulic ${ }^{14}$. Domy budowano z drewna, niektóre $\mathrm{z}$ nich posiadały tzw. stajnie wjezdne, będące pewną formą zajazdów, gdzie za stosowną opłatą mogli zatrzymywać się przybywający na targi i jarmarki kupcy oraz inni przejezdni. Wizytator nakazał, aby wszyscy mieszczanie posiadający tego typu domostwa zawarli z zakonnicami kontrakty określające warunki ich prowadzenia, ze względu na fakt, iż zyski z tego typu działalności we wszystkich prywatnych miastach należą do właścicieli. Natomiast nowobudowane domy powinny być pozbawione tego typu stajen, bądź posiadać zgodę ksieni na ich postawienie $^{15}$.

Najbardziej okazałą budowlą w mieście był kościół parafialny pw. Niepokalanego Poczęcia Najświętszej Maryi Panny „murowany z kamienia z przytykiem

${ }^{9}$ ANI, G 6, s. 6. Por. Kiryk, Dzieje Buska, s. 20

${ }^{10} \mathrm{~J} . \mathrm{Ph}$. Carosi, Reisen durch verschidene polniche Provinzen, mineralogichen und anderen Inhalt, Leipzig 1781, s. 217, 218 za: Guldon, Stępkowski, Busko na tle miast, s. 30-31.

${ }^{11}$ ANI, G 6, s. 120-121.

${ }^{12}$ Tamże, s. 121.

${ }^{13}$ S. Marcinkowski, Busko w okresie rozbiorów i niewoli (1795-1914), „Studia Kieleckie”, 3/47 (1985), s. 43-44.

${ }^{14}$ Carosi, Reisen durch verschidene, s. 217, 218 za: Guldon, Stępkowski, Busko na tle miast, s. $30-31$.

${ }^{15}$ ANI, G 6, s. 121. 
do klasztoru WW. PP. Zakonnych, cały sklepiony" ${ }^{\prime 16}$. Pamiątkę jego konsekracji obchodzono w pierwszą niedzielę po święcie Wniebowzięcia NMP.

Ponieważ większa część zabudowy miasta, w tym również kościół, spłonęła w 1820 roku interesującym wydaje się odtworzenie jego wyglądu w świetle istniejącej wizytacji.

Wejście główne od południa prowadziło przez podwójne drzwi z zamknięciem do kruchty, zaś boczne wiodło także przez podwójne drzwi prosto do kościoła. Kruchta wyłożona została kamienną posadzką, sufit wykonano z tarcic a cały przedsionek pobielono. Z kruchty prowadziło przejście przez duże dwuskrzydłowe podwoje do świątyni. Wewnątrz znajdowały się dwie sklepione i pokryte kopułami kaplice, jedna św. Anny a druga św. Barbary (zlokalizowana pod chórem) oraz murowana, sklepiona zakrystia. W kościele znajdowały się dwa chóry tzw. panieński, wsparty na kamiennych filarach i w bocznej części drugi, drewniany nazwany muzycznym od znajdujących się na nim organów. Dziewięć okien różnej wielkości zapewniało świątyni odpowiednią ilość światła. Środkową część kościoła, w miejscu lokalizacji ławek, wyłożono drewnianą podłogą z tarcic, natomiast pozostała część, zakrystia i kaplice miały posadzkę kamienną. Po obydwu stronach kościoła ustawiono cztery konfesjonały.

Wystrój wnętrza przedstawiał się dość imponująco. Centralne miejsce zajmował ołtarz zwany wielkim. Umieszczono go na murowanej mensie, posiadał drewniany portatyl ozdobiony złoceniami, chociaż zaznaczono, że wykonany był „staroświecka robota”. W nim umieszczono obraz Matki Boskiej Niepokalanego Poczęcia, który dzięki specjalnej zasuwie można było przysłaniać. Ponad obrazem znajdowało się drewniane cyborium, ozdobione rzeźbionymi postaciami osób, całość ze względu na złocenia stanowiła wraz z portatylem jedność kompozycyjną.

Oprócz wspomnianego, w kościele było jeszcze osiem drewnianych ołtarzy, niektóre z nich jedynie pomalowano, inne posiadały ozdobne złocenia. Do ołtarzy wspierających się na murowanej mensie, posiadających portatyle należały: Różańcowy, Opieki Najświętszej Panny Maryi, Świętej Tekli, Świętych Augustyna i Norberta, Swiętej Barbary pod chórem, Świętej Anny posiadający zasuwę przysłaniającą obraz i Świętej Jadwigi określany jako mały, na temat dwóch ostatnich wzmiankowano, iż były konsekrowane. Kolejne dwa ołtarze Świętego Jana Nepomucena i Świętego Antoniego posiadały drewniane mensy.

$\mathrm{Z}$ drewna wykonana była także ambona, pomalowano ją i ozdobiono złoceniami. Zamiast tęczy na murze pod sklepieniem przymocowano krucyfiks ${ }^{17}$.

W związku z dużą liczbą wiernych, którzy nie mogli się pomieścić w kościele ze względu na niewielką powierzchnią budowli, wizytator w 1782 roku nakazał przesunięcie pod ściany boczne ławek, likwidację balasek od ołtarza Św. Tekli i usunięcie czterech ołtarzy: Świętej Anny, Świętego Jana Nepomucena, Świętego Antoniego, Świętych Augustyna i Norberta. Obrazy z nich miały być umieszczone w różnych miejscach, zarówno w kościele jak i w klasztorze ${ }^{18}$. Na miejsce ołtarza

\footnotetext{
${ }^{16}$ ANI, G 6, s. 6.

${ }^{17}$ Tamże, s. 6-8.

${ }^{18}$ Tamże, s. 109-111.
} 
Św. Anny w kaplicy nazwanej jej imieniem miała być przeniesiona chrzcielnica, która dotychczas była „w zakacie stojaca i niewidoczna”"19.

Spis naczyń, szat liturgicznych i innych wartościowych przedmiotów zamieszczony został $\mathrm{w}$ aneksie ${ }^{20}$.

Świątynia na zewnątrz wyglądała też okazale. Pokrycie wykonano z dachówki, w centralnej części dachu górowała kopuła z sygnaturką zabezpieczona białą blachą, blachę umieszczono też na kopułach kaplic Swiętej Anny i Swwiętej Barbary, nad zakrystią i kruchtą. W narożnej części kościoła, od strony klasztoru postawiono wieżę, gdzie zegar odmierzał czas w godzinnych odstępach.

Wokół kościoła rozpościerał się „opasany murem przystojnie” cmentarz, na który od strony miasta prowadziła brama z furtką, dwie inne furtki były zlokalizowane od zachodu i wschodu. Tutaj również widać było dbałość o otoczenie, murowaną z kamieni kostnicę wraz z komorą na sprzęty pokrywał gontowy dach a całość zabezpieczał solidny zamek. Na cmentarzu przykościelnym było też miejsce na drewnianą dzwonnicę na podmurówce, wokół obłożono ją tarcicami, wierzch pokryto gontami a wewnątrz zawieszono trzy dzwony - mały, średni i duży. Wizytator zalecil, aby w ciągu najbliższych trzech lat zakonnice wybudowały na jej miejscu dzwonnicę murowaną. Natomiast sama świątynia była odnowiona i wyremontowana w 1782 roku, o czym również nie omieszkał wspomnieće ${ }^{21}$.

Drugi niewielki kościółek pod wezwaniem św. Leonarda znajdował się „w końcu miasta”, był zbudowany z drewna, obity wokół tarcicami, pokryty dachem, zapewne z gontów, z kopułką z białej blachy w jego środkowej części, w której zawieszono solidnie osadzony dzwonek. W porównaniu do kościoła farnego był bardzo skromnie urządzony i wymagał remontu.

Wejście wiodło poprzez kruchtę ze ścianami z tarcic i podłogą z tego samego materiału, drewno jednak było już spróchniałe. Pierwsze i jedyne drzwi znajdowały się między kruchtą a kościołem. Wyposażenie stanowił ołtarz wielki umieszczony na murowanej mensie ze statuą św. Leonarda, którą można było przysłonić zasuwą. Przy bocznych ścianach na stołach znajdowały się dwa drewniane, małe, zniszczone ołtarzyki. Dostojności świątyni dodawała tęcza z krucyfiksem i dwoma rzeźbami nieokreślonych postaci. Znajdował się tu również niewielki chór, na który wiodły częściowo zniszczone schody i mała, obita tarcicami zakrystia oraz ławki po obydwu stronach kościoła. Zarówno posadzka wykonana z białego kamienia jak i stara, drewniana powała wymagały również szybkiej naprawy. Wizytator zalecił, aby dwa ołtarze z kościoła parafialnego - Św. Jana Nepomucena i Św. Antoniego „dla większej [...] ozdoby" były przeniesione do tego kościółka ${ }^{22}$.

Zgodnie z tradycją na placu wokół kościoła znajdował się cmentarz ogrodzony parkanem sosnowym ,w słupach, dylach, przycioskach i płatwach”, wejście na jego teren stanowiły podwójne wrota $\mathrm{z}$ zamknięciem oraz stale zamknięta furtka ${ }^{23}$.

\footnotetext{
19 Tamże, s. 110.

${ }^{20}$ Patrz aneks tekst nr 1.

${ }^{21}$ ANI, G 6, s. 8-9, 131.

22 Tamże, s. 10-11, 110-111.

23 Tamże, s. 11.
} 
W związku z dużą ilością pogrzebów, kształtującą się na poziomie około 150 rocznie wizytator zalecił, ażeby zmarłych w okresie od 1 maja do 30 października grzebano na cmentarzu przy kościele św. Leonarda a pozostałych na cmentarzu parafialnym. Wyjątek stanowić mieli jedynie ci, których doczesne szczątki zgodnie z ich wolą bądź rodziny miały spocząć w grobach kościoła farnego. Uroczystości żałobne miały być odprawiane również w kościele św. Leonarda. Ponieważ dotychczas nabożeństwa sprawowano tu jedynie sporadycznie, brak było aparatów liturgicznych należało na okres letni przenieść potrzebne szaty i naczynia religijne do tej świątyni ${ }^{24}$.

Tekst wizytacji zawiera niewiele wzmianek na temat samego klasztoru. Wiemy, iż „kościół murowany z kamienia [był] z przytykiem do klasztoru”, prowadziły z niego pojedyncze drzwi do konwentu wybudowanego na planie kwadra$t^{25}$. W 1781 roku klasztor został ,ze wszystkim wewnątrz i zewnątrz wyreperowany i w swoich częściach wytynkowany"26. Możemy sądzić, że stan zabudowań klasztornych był dobry, naprawy, podwyższenia i obwiedzenia daszkiem wymagał jedynie „mur około ogrodu klasztornego bardzo w niektórych miejscach niski i zepsuty"27.

W kierunku na wschód od kościoła i klasztoru znajdował się wyremontowany, z nowym pokryciem budynek stanowiący mieszkanie księży. Były w nim trzy izby z alkierzami zajmowane przez duchownych i czwarta dla rzemieślników, którzy wykonywali prace przy kościele i klasztorze. Obok wybudowano mieszkanie dla pisarza klasztornego.

Idąc dalej na wschód można było dojść do jednego z trzech folwarków klasztornych położonych na terenie miasta. Przejście wiodło przez bramę z solidnymi wrotami, za nią rozpościerały się murowane facjaty, dwa lamusy z nowym dachem, dalej drewniany folwark $\mathrm{z}$ dwoma mieszkaniami a naprzeciwko niego piekarnia. Za domem folwarcznym zbudowano na planie kwadratu oborę, dalej stajnię z tarcic w słupy z nowym dachem, obok schowek na sprzęty gospodarskie. Niezwykle ważną budowlą był spichlerz usytuowany naprzeciwko bramy gospodarczej prowadzącej do klasztoru, wewnątrz wydzielono trzy komory z zamknięciami, wybudowano go z drewna i pokryto nowym dachem. W skład zabudowań gospodarczych wchodził też murowany browar z suszarnią. Wyposażenie jego stanowił kocioł do warzenia piwa i inne niezbędne do produkcji piwa naczynia. Jedynym mankamentem budynku był nieco popsuty dach. Browar i spichlerz oddzielony był od reszty zabudowań klasztornych murem zakończonym daszkiem, tutaj też usytuowano bramę łączącą podwórze gospodarcze klasztoru i folwark. $\mathrm{Na}$ terenie folwarku było też gumno zbudowane z drewna na planie kwadratu, część jego naprawiono, ale reszta wymagała szybkiego remontu.

Wybudowano tu także mieszkanie dla ogrodnika składające się z izby, komory i sieni, wyremontowane i pokryte słomą. Ogrodnik odpowiadał za pielęgnację warzyw w ogrodzie tzw. włoskim, który był na zachód od klasztoru i wokół ota-

\footnotetext{
${ }^{24}$ Tamże, s. 110.

${ }^{25}$ Tamże, $6,8$.

${ }^{26}$ Tamże, s. 67.

${ }^{27}$ Tamże, s. 129-130.
} 
czał go nieco zdezelowany mur. Dbał też o rośliny w drugim ogrodzie otoczonym parkanem i płotem oraz o sad śliwowy. Fakt odgrodzenia murem ogrodu włoskiego od reszty zabudowań gospodarczych dawał norbertankom możliwość przebywania w nim w celach rekreacyjnych oraz pielęgnowanie roślin.

Na terytorium miejskim norbertanki posiadały też folwark Targowski położony w kierunku drogi na Owczary. Jak wynika z opisu budynek folwarczny był w dość kiepskim stanie, dwa mieszkania z sieniami, komorami i izbą zniszczone a słomiany dach potrzebował wymiany. Drugi z folwarków usytuowany był za kościołem św. Leonarda i stanowił darowiznę mieszczki buskiej Reginy Zawadzkiej. Budynek postawiono z drewna w węgieł, było w nim cztery mieszkania do których wiodły dwie sienie, całość pokrywał dach będący w dobry stanie. Obok zabudowań znajdowała się studnia ${ }^{28}$.

Do zabudowań klasztornych zaliczyć trzeba też dom dla zakrystianina, położony w kierunku na zachód od cmentarza przy kościele farnym. Była to budowla murowana, wyremontowana, składająca się z sieni, izby i komory, naprawy wymagało jedynie poszycie dachu. Dla pozostałej służby kościelnej przeznaczono drewniany budynek położony obok muru klasztornego, w pobliżu ogrodu. Były w nim trzy mieszkania składające się z izby i komory, jedno zajmował kantor, drugie organista a trzecie było wolne. Jedynym mankamentem owego lokum był zniszczony dach ${ }^{29}$.

Naprzeciwko kościoła parafialnego usytuowano szpital spełniający rolę przytułku a ,w nim [zamieszkiwali] podupadli mieszczanie i mieszczki”" ${ }^{30}$. Była to budowla $\mathrm{z}$ tarcic w węgieł, wewnątrz mieściła dużą izbę stanowiącą miejsce zamieszkania ubogich, komorę i sześć zamykanych komórek do przechowywania różnych rzeczy. W pobliżu szpitala postawiono małą, pokrytą słomą stodołę. Całość zabudowań była w dobrym stanie.

W 1782 roku w szpitalu przebywało „dwóch dziadów i bab sześć w liczbie osi[e]m osób ubogich"31. Urząd prowizora sprawował ówczesny wójt Buska Tomasz Ryszkowski. Na użytek mieszkańców przeznaczone było bydło - krowa z jałówką i para koni oraz pochodzące z legatów czynsze i grunty. W 1646 roku podsędek ziemski sandomierski Wojciech Maksymilian z Żukowa Żukowski zapisał na rzecz 12 ubogich zamieszkujących w domu szpitalnym na swoich dobrach dziedzicznych Zbludowice sumę 400 talarów z których roczny czynsz wynosił 28 talarów. Zastrzegł również, aby naprzemiennie „,w pierwszym roku tym dwunastu ubogim odzież i obuwia sprawiane były, drugiego zaś roku kożuchy dobre i tak na przemian wiecznemi czasy"32. W zamian ubodzy szpitalni byli zobowiązani do codziennego uczestniczenia w pierwszej w danym dniu Mszy św. odprawianej w kościele farnym, modlitwy w intencji fundatora i ,za wszystkich Najjaśniej-

${ }^{28}$ Tamże, s. 67-69.

29 Tamże, s. 67-69.

${ }^{30}$ Tamże, s. 115. O istnieniu przy kościele parafialnym przytułku czytamy też pod koniec XVI wieku. Por. Kiryk, Dzieje Buska, s. 22.

${ }^{31}$ ANI, G 6, s. 19-20.

32 Tamże, s. 17. 
szych Królów Polskich i za ciągłość Rzeczypospolitej”33. Pomimo odnowienia w 1765 roku powyższego legatu ówczesny dziedzic Zbludowic niejaki Ożarowski nie wypłacał szpitalowi należnego czynszu.

Ponadto na rzecz szpitala legowane było 100 złp a zapis uczyniony został na gruncie miejskim Grzegorza Nowakowskiego i druga taka sama suma na gruncie mieszczanina buskiego Wacława Muszyńskiego, który ponadto przekazał na „ten szpital trzy chałupki swoje dziedziczne, z których [szpital] bierze corocznie czynszu po złł 10 in summa złł 30" "34. Znajdowały się one w następujących miejscach: pierwsza przed furtką wiodącą na cmentarz a dwie kolejne przy ulicy Kościelnej. Były to budowle drewniane, pokryte dachem z sieniami i komorami a przy jednej $\mathrm{z}$ nich usytuowano mały chlew ${ }^{35}$.

Własnością szpitala były też pola uprawne. Pierwsze z nich darowane niegdyś przez niejakiego Krolewskiego o powierzchni 300 zagonów, rozpościerające się „między gruntami z jednej strony kaznodziejskiej roli, z drugiej strony Józefa Pochwalskiego" przynosiło czystego zysku rocznie $20 \mathrm{złp}^{36}$. Druga rola wielkości 100 zagonów zasilała kasę szpitalną rocznie w sumę 15 złp a położona była pomiędzy gruntami mieszczanina buskiego Jana Kantego Sustalskiego a nieznanego z imienia Mrugalskiego i gruntami nazywanymi Bależowszczyna. Wymieniane pola były oddawane w dzierżawę, natomiast dwa kolejne poletka uprawiali mieszkańcy szpitala. Była to rola „między drogami Kolelską i Welecką w Busku za kościółkiem S. Leonarda przy roli Józefa Pochwalskiego mieszczanina buskiego" o powierzchni 60 zagonów i ogród „przy gościńcu chmielnickim przy gliniankach za ogrodem klasztornym" ${ }^{37}$.

Wizytator podkreślał, iż norbertanki, mieszczanie i prowizor powinni wspólnie dbać o dom szpitalny i środki na jego utrzymanie ${ }^{38}$. Decyzje w sprawie zawiadywania gruntami i funduszami należały do kompetencji prowizora. Ze względu na wielkość czynszów z lokowanych sum, które mogły w przyszłości przynosić mniejsze niż pięcioprocentowe dochody, aby nie uszczuplić profitów szpitala, prowizor wraz z komisarzem klasztoru powinni oszacować wielkość wydatków i zagwarantować takie wpływy, jakie były niezbędne na utrzymanie ubogich. Bilans percepty i ekspensy miał być sporządzany każdego roku w ostatnich dniach miesiąca grudnia przez prowizora w obecności komisarza klasztoru i wójta miasta oraz przez nich zatwierdzany.

${ }^{33}$ Tamże, s. 17.

${ }^{34}$ Tamże, s. 18.

${ }^{35}$ Tamże, s. 72.

${ }^{36}$ Tamże, s. 18 ,

${ }^{37}$ Tamże, s. 19.

${ }^{38}$ Tamże, s. 115. „Szpital czyli dom szpitalny, ile w nim podupadli mieszczanie i mieszczki mieścić się mają, konwent przez wzgląd na swych poddanych, mieszczanie przez wzgląd na swych ziomków, prowizor przez wzgląd na dochody szpitalne wzajemnie i równie stawiać, naprawiać i utrzymywać będą". 
Ponadto nakazane zostało, aby prowizor umieścił w kruchcie kościelnej skrzynkę „,napisawszy nad nią jałmużna dla ubogich”39. Klucze od skrzynki opróżnianej kwartalnie miały znajdować się u prowizora i komisarza klasztoru a uzyskana jałmużna przeznaczana być miała na potrzeby ubogich z domu szpitalnego. W zamian biskup zobowiązał szpitalników do kwartalnej spowiedzi i Komunii św. oraz odmawiania modlitw za ofiarodawców ${ }^{40}$.

Drugą obok szpitala ważną instytucją w mieście była szkoła. Tradycje oświatowe w Busku sięgały przełomu XIII i XIV wieku, w tym czasie chłopcy uczęszczali do szkółki parafialnej. Pod koniec XVI stulecia budynek szkolny wystawiony z kamienia mieścił się w zachodniej części cmentarza, a niektórzy jej absolwenci podejmowali studia na uniwersytecie krakowskim ${ }^{41}$. Na podstawie protokołu wizytacyjnego z 1782 roku trudno jednoznacznie określić, czy w tym czasie funkcjonowała szkółka parafialna ${ }^{42}$. Wiemy na pewno, że w domu stojącym na cmentarzu kościelnym, gdzie mieściła się dawniej szkoła, zamieszkiwał dzwonnik. Być może nauka była prowadzona w tym budynku lub całkowicie jej zaprzestano. Wizytator przypomniał, iż obowiązek budowy i prowadzenia szkoły spoczywał na zakonnicach, ale w razie pożaru lub zniszczenia obiektu mieszczanie mieli dostarczyć materiał na jej odbudowę oraz ponieść połowę kosztów związanych z jej wystawieniem. Ponieważ lokum na szkołę było, musiał opuścić je jedynie dzwonnik, i budynek mógł być przywrócony do pełnienia swojej poprzedniej funkcji.

Wytyczne wizytatora określały, że zarząd nad szkołą powinien sprawować dyrektor, który miał otrzymać również mieszkanie w jej budynku. O właściwego kandydata na to stanowisko powinni postarać się mieszczanie, ale ostateczna decyzja w sprawie zatrudnienia zależała od opinii komisarza klasztoru i ksieni: „Tego wyegzaminowanego przez J. ks. komendarza z[e] zdolności, obyczajów i nauki, za pokorną mieszczan prośbą Jej M[oś]ć Panna Ksieni przyjmuje a z[e] słusznych przyczyn dla zdrożności, niedbalstwa, hardości i nieposłuszeństwa odprawi" "43. Dyrektor miał otrzymywać kwartalnie wynagrodzenie z klasztoru w wysokości 10 złp ,za usługi w kościele, powolność w rozkazach klasztoru, processyje i pomaganie śpiewania kantorom kościelnym” a ponadto „mieszczanie zaś od dzieci swych uczących się płacić mu będą kwartalnie jak się ugodzą, stół kolejno

${ }^{39}$ Tamże, s. 116. „Zaleci zaś J ks. komendarz lub J ks. kaznodzieja po wiele razy w kościele, aby jałmużnicy w tę skrzynkę wkładali. Boć nie każdego stać, aby wszystkim ubogim, których tu z przychodniów bardzo wiele jest, w szczególności dana była jałmużna a wielu stać może, włożyć mniej lub więcej dla wszystkich na podział w [s]karbonkę".

${ }^{40}$ Tamże, s. 116.

${ }^{41}$ Por. Kiryk, Dzieje Buska, s. 23-24.

42 Szkoła na pewno istniała w 1737 roku, ponieważ w zestawieniu wydatków klasztornych z tego roku znajduje się zapis: Szkolnym. Kantorowi 24 złp. Organiście 24 złp. Dyrektorowi 24 złp. Na godzinki tymże szkolnymna rok 14 złp. Dzwonnikowi 24 złp. Por. ANI, rps G 5, Kronika klasztoru SS. Norbertanek w Busku, obłóczyny, profesje (1737-1814). Expens roczny pieniężny pod klasztorem y folwarkach przyległych konwentowi buskiemu za godnego przełożeństwa nayprzewielebnieyszey JMJ Panny Joanny Katarzyny Bobrownicki xieni tegoż konwentu od roku 1737 spisany, s. 19.

${ }^{43}$ ANI, G 6, s. 114. 
opatrywać i w piecu na zimie palić, także kolejno raz przynajmniej na tydzień" ${ }^{\prime 4}$. Nie wiemy, jaki program nauczania miał być realizowany w szkole, ale na pewno dzieci powinny być uczone śpiewów kościelnych, w tym godzinek, aby wspólnie ze służbą klasztorną uczestniczyć czynnie w nabożeństwach ${ }^{45}$.

Oprócz szkoły dla dzieci mieszczan buskich prowadzona była w klasztorze, wewnątrz klauzury, pensja dla dziewcząt. Norbertanki przyjmowały na wychowanie panienki pochodzące głównie z rodzin szlacheckich i zajmowały się nie tylko kształtowaniem ich charakteru, ale przekazywały wiedzę elementarną i nauczały języków obcych - francuskiego i niemieckiego. Wizytator zachęcał do zatrudnienia do nauczania języków obcych świeckich nauczycielek, nazywanych mistrzyniami świeckimi, twierdząc, że „dobro publiczne i sąsiedzkie [będzie] miało z nich wygodę, pomoc i pociechę [...] sławę [to] klasztorowi uczyni, zysk pewny przyniesie, protektorów pomnoży, szemrzącym o to zamknie usta"46. O efektach edukacji możemy przekonać się kart kroniki klasztornej, kiedy podczas wizyty Stanisława Augusta Poniatowskiego w Busku w 1787 roku wśród witających króla były również uczennice szkoły klasztornej, które pozdrowiły go po polsku, francusku i niemiecku ${ }^{47}$.

Ważną rolę we właściwym wychowaniu dzieci i rozwoju duchowości parafian odgrywały nabożeństwa i katechizacja wiernych. Duchowni wygłaszali kazania w każdą niedzielę i święto a ponadto w te dni w godzinach popołudniowych pleban miał obowiązek prowadzić katechizację dla tych parafian, którzy nie znali zasad wiary ${ }^{48}$.

W 1782 roku przy parafii w Busku posługę pełniło czterech duchownych: ks. Marcin Bąkiewicz ${ }^{49}$ komisarz klasztoru i spowiednik, norbertanin ks. Grzegorz Kretkowski ${ }^{50}$ pełniący urząd spowiednika zakonnic i osób świeckich, ks. Kamil Szeliski $^{51}$ ojciec będący kaznodzieją i spowiednikiem oraz ksiądz Antoni Klu-

${ }^{44}$ Tamże, s. 114-115.

${ }^{45}$ Tamże, s. 115. „Dyrektor przysposobi dzieci uczące się, aby razem na prymaryi z służebnemi klasztornemi przez strofy śpiewały Godzinki o Niepokalanym Poczęciu N. Panny Maryi".

${ }^{46}$ Tamże, s. 125.

${ }^{47}$ ANI, G 5, s. 7.

${ }^{48}$ ANI, G 6, s. 108-109. Katechizacja nie była prowadzona w Niedzielę Wielkanocną, w niedzielę między oktawą Bożego Ciała, Bożego Narodzenia, w te niedziele, w które przypadały odpusty z wystawieniem Najświętszego Sakramentu oraz w czasie miesięcy letnich - od lipca do października.

${ }^{49}$ Tamże, s. 98. Ks. Marcin Bąkiewicz ur. w 1724 r., kapłan od 1752 r., od 1758 r. komisarz klasztoru norbertanek w Busku, od 23 VIII 1782 r. zatwierdzony na pół roku do słuchania spowiedzi zakonnic.

${ }^{50}$ Tamże, s. 98. Ks. Grzegorz Kretkowski ur. w 1708 r., kapłan od 1733 r., profesja w klasztorze norbertanów w Witowie, od 1744 r. „służy temu miejscu za obedyencją przełożonych swoich” jako spowiednik.

${ }^{51}$ Tamże, s. 98. Ks. Kamil Szeliski ur. w 1746 roku, kapłan od 1772 r., profes witowski, kaznodzieja i spowiednik zakonnic, służył przy klasztorze w Busku od 1776 r. 
szyński ${ }^{52}$ zarządzający dobrami klasztornymi i w razie potrzeby pełniący funkcję spowiednika. Ponadto do służby kościelnej należeli organista Ludwik Gromski, kantor Maciej Dębnicki, podkantor Marcin Borzęcki i zakrystianin Franciszek Czerwiński ${ }^{53}$.

Czynnikiem integrującym parafian i wpływającym na rozwój religijności były bractwa religijne. Przy kościele farnym istniały w II połowie XVIII wieku dwie konfraternie - Bractwo Różańca Świętego i Bractwo Świętej Anny. Pierwsze z nich należało do grupy bractw maryjnych. W Rzeczypospolitej w XVIII wieku były one najliczniejsze, stanowiły $54 \%$ wszystkich bractw ${ }^{54}$. Jednak jego początki w Busku były dużo wcześniejsze, ponieważ powstało 13 czerwca 1581 roku. Na czele stał prowizor, od 9 marca 1780 roku był nim mieszczanin Józef Jeziorowski ${ }^{55}$. Nie znamy składu osobowego bractwa, ale wiemy, że uzyskiwało stałe dochody z kapitału pochodzącego z legatów.

Wykaz posiadanych kapitałów wraz z nazwiskami donatorów znajduje się w poniższej tabeli nr 1 .

\section{Tabela 1. Kapitały Bractwa Różańca Świętego w Busku w 1782 roku}

\begin{tabular}{|c|c|c|c|c|}
\hline L.p. & Imię i nazwisko donatora & $\begin{array}{c}\text { Suma } \\
\text { w zł }\end{array}$ & Imię i nazwisko osoby opłacającej prowizję & $\begin{array}{c}\text { Suma lokowana } \\
\text { w zł }\end{array}$ \\
\hline \multirow{2}{*}{1.} & \multirow{2}{*}{ Jan Nowak } & \multirow{2}{*}{200} & Stanisław Jurecki & 100 \\
\hline & & & Jadwiga Gorelówna & 100 \\
\hline \multirow{5}{*}{2.} & \multirow{5}{*}{ Regina Zawadzka } & \multirow{5}{*}{450} & Jakubowa Bulińska wdowa & 100 \\
\hline & & & Stanisław Grzybowski & 100 \\
\hline & & & Marcin Orłowski & 100 \\
\hline & & & Stanisław Wawrzykiewicz & 100 \\
\hline & & & Jan Kanty Świtalski & 50 \\
\hline 3. & Stanisław Chyzicki & 100 & Tomasz Ryszkowski & 100 \\
\hline \multirow{2}{*}{4.} & \multirow{2}{*}{ Paweł Mątkowski } & \multirow{2}{*}{200} & sukcesorowie Stanisława Nestorowicza & 100 \\
\hline & & & Tomasz Chutkiewicz & 100 \\
\hline \multirow{2}{*}{5.} & \multirow{2}{*}{ Wojciech Stachowicz } & \multirow{2}{*}{150} & Marcin Przybyłowicz & 100 \\
\hline & & & Piotr Gorelowicz & 50 \\
\hline 6. & Kobies z Owczani & 100 & Mikołaj Nowakowski mieszczanin buski & 100 \\
\hline
\end{tabular}

Źródło: ANI, G 6, s. 20-21.

Całkowity kapitał bractwa w 1782 roku wynosił 1200 zł i pochodził z zapisów Jana Nowaka, Reginy Zawadzkiej, Stanisława Chyzickiego, Pawła Mątkow-

${ }^{52}$ Tamże, s. 99. Ks. Antoni Kluczyński ur. w 1752 r., kapłan od 1776 r., od 1782 r. zarządzający dobrami norbertanek buskich, spowiednik.

${ }^{53}$ Tamże, s. 99. Ludwik Gromski lat 33, od 9 lat organista; Maciej Dębnicki kantor lat 60, od 14 lat pełnił służbę; Marcin Borzęcki lat 22, podkantor od 4 lat; Franciszek Czerwiński lat 29, od 5 lat zakrystianin.

${ }^{54}$ S. Litak, Atlas kościoła katolickiego w Rzeczypospolitej Obojga Narodów w XVIII wieku, Lublin 2006, s.52. Por. J. Flaga, Bractwa religijne w Rzeczypospolitej w XVII i XVIII wieku, Lublin 2004, s. 90-95.

${ }^{55}$ ANI, G 6, s. 9, 21. 
skiego, Wojciecha Stachowicza i „pracowitego" Kobiesa z Owczarni. Wysokość legatów była różna i wynosiła od 100 do 450 zł, wszystkie one były umieszczone na majątkach 13 osób, spośród których w jednym przypadku wiadomo, iż był nim tutejszy mieszczanin Mikołaj Nowakowski. Nadmienić należy, iż lokowane sumy wynosiły od 50 do $100 \mathrm{zł}$, co wydaje się słuszne, ponieważ w przypadku niewypłacalności należnych procentów lub przepadku mienia danej osoby istniało mniejsze niebezpieczeństwo utraty dochodów. Nie znamy wysokości czynszów, jednak jeśli przyjmiemy, że mogło to być minimalnie 3 a maksymalnie 5\% to daje to sumę od 36 do 60 zł rocznie ${ }^{56}$.

Druga konfraternia poświęcona świętej Annie zaczęła funkcjonować pod koniec XVI wieku. Zgoda na jej utworzenie została wydana przez papieża Grzegorza XIII w 1581 roku, pierwsze pozwolenie władzy diecezjalnej datowane było w 1586 roku, a druga erekcja bractwa nastąpiła w 1597 roku $^{57}$. Trudno dzisiaj wyjaśnić, dlaczego dopiero po kilkunastu latach od powstania idei powołania Bractwo św. Anny rozpoczęło działalność. Szczególną aktywność w tym czasie wykazywał Zygmunt Urbański norbertanin i proboszcz kościoła w Busku, który w 1601 roku ufundował $\mathrm{z}$ własnych pieniędzy przy kościele farnym dla tego bractwa kaplicę św. Anny i zapisał sumą 500 zł pochodzącą „z ojczystej fortuny" lokowaną na wyderkauf na dobrach Zbludowice ${ }^{58}$. W 1610 roku była to organizacja dobrze uposażona, pobierająca oprócz wspomnianego wyżej, także czynsz w wysokości 24 zł rocznie, pochodzący z zapisu szlachcica Tomasza Kowalkowskiego na wsi Zbludowice ${ }^{59}$. Kolejne zapisy na rzecz bractwa czynione były w następnych latach. Brak nazwisk innych dobrodziejów bractwa, zachował się jedynie wykaz mieszczan, na dobrach których w 1782 roku były złożone kapitały konfraterni (tabela 2).

Tabela 2. Kapitaly Bractwa Świętej Anny w 1782 r.

\begin{tabular}{|c|l|c|}
\hline L.p. & \multicolumn{1}{|c|}{ Imię i nazwisko osoby opłacającej czynsz } & suma lokowana w zł \\
\hline 1. & Józef Jeziorowski & 200 \\
\hline 2. & Jan Kanty Switalski & 150 \\
\hline 3. & Ludwik Piotrowski & 100 \\
\hline 4. & Piotr Gorelowicz & 100 \\
\hline 5. & Antoni Ryszkowski & 100 \\
\hline 6. & Walenty Bożęcki & 100 \\
\hline 7. & Wojciech Rydzy & 100 \\
\hline 8. & Mikołaj Nowakowski & 100 \\
\hline 9. & Mikołaj Nowakowski & 50 \\
\hline 10. & Grzegorz Nowakowski & 50 \\
\hline 11. & Gurczyńska wdowa & 100 \\
\hline 12. & Maryanna Wóycikowiczowa wdowa po Grzegorzu Bożęckim & \\
\hline
\end{tabular}

56 Tamże, s. 20-21.

57 Tamże, s. 9, 21.

58 Tamże, s. 21.

${ }^{59}$ Por. Kiryk, Dzieje Buska, s. 23. Bractwa św. Anny były skierowane przeciw innowiercom, miały też charakter dewocyjny, charytatywny i towarzyski. 


\begin{tabular}{|c|l|c|}
\hline 13. & Norbert Pastwiński & 100 \\
\hline 14. & Marcin Przybyłowicz & 100 \\
\hline 15. & Jan Ciepliński & 100 \\
\hline
\end{tabular}

Źródła: ANI, G 6, s. 22.

Wielkość zgromadzonego kapitału wynosiła w 1782 roku 1450 zł i była zabezpieczona się na majątkach mieszczan buskich. Podobnie jak w przypadku Bractwa Różańcowego roczny dochód z lokowanych sum mógł wynosić około 43 zł 15 gr (3\%) do 72 zł 15 gr.(5\%), ponadto organista płacił czynsz za użytkowanie ogrodu 3 zł a Sebastian Chyzicki ze swego gruntu 2 zł rocznie ${ }^{60}$.

Uzyskiwane fundusze przeznaczane były na utrzymanie ołtarzy brackich, zakup oświetlenia, opłacenie Mszy św. i nabożeństw za zmarłych i żyjących członków konfraterni. Bractwo Różańcowe miało pod opieką Ołtarz Różańcowy, przy którym z własnych dochodów opłacało comiesięczne Msze św. za dusze fundatorów bractwa i sobotnie wotywy śpiewane za jego członków ${ }^{61}$.

Warto wspomnieć, iż przy tym ołtarzu były sprawowane wotywy za członków Bractwa Literackiego, które najpewniej istniało tu w średniowieczu a w XVI wieku ustąpiło miejsca Bractwu Świętej Anny ${ }^{62}$. To ostatnie opiekowało się ołtarzem św. Anny i w każdy wtorek sprawowane były przy nim śpiewane wotywy za żyjących członków a raz na kwartał odprawiano Msze św. suchedniowe ${ }^{63}$.

W protokole powizytacyjnym czytamy, że członkowie bractw powinni zadbać też o oświetlenie ołtarza głównego, określić ilość dostarczanego w ciągu roku wosku oraz pomagać zakrystianinowi w ustawianiu świec i przystrajaniu ołtarza ${ }^{64}$.

Posiadamy również informacje na temat wszystkich nabożeństw odprawianych w 1782 roku przypisanych do poszczególnych ołtarzy w związku z dokonanymi legatami. Wykaz ich zawarty jest w tabeli nr 3.

Tabela 3. Wykaz nabożeństw sprawowanych przy poszczególnych oltarzach w kościele farnym w $1782 \mathrm{r}$.

\begin{tabular}{|c|c|c|c|c|}
\hline L.p. & Nazwa ołtarza & Rodzaj nabożeństwa & $\begin{array}{c}\text { Częstotliwość } \\
\text { odprawiania }\end{array}$ & Intencja/określający intencję \\
\hline \multirow[b]{2}{*}{1.} & \multirow{2}{*}{$\begin{array}{l}\text { Ołtarz } \\
\text { Niepokalanego } \\
\text { Poczęcia NMP }\end{array}$} & Msza św. czytana & raz w tygodniu & za fundatorów \\
\hline & & Msze św. śpiewane & 5 razy $w$ roku & cech szewski \\
\hline 2. & Ołtarz św. Norberta & Msze św. czytane & 4 razy w roku & cech piekarski \\
\hline \multirow[t]{2}{*}{3.} & \multirow[t]{2}{*}{ Ołtarz św. Jadwigi } & Msze św. & 4 razy w roku & $\begin{array}{l}\text { obligacja z } 21 \text { VIII } 1646 \\
\text { r. w Krakowie, wdowa } \\
\text { Pakoszowa zapisała klasztorowi } \\
\text { „pręt roli z folwarczkiem” }\end{array}$ \\
\hline & & Msze św. & 5 razy w roku & cech krawiecki \\
\hline
\end{tabular}

\footnotetext{
${ }^{60}$ ANI, G 6, s. 22.

61 Tamże, s. 12. Por. tab. 3.

${ }^{62}$ Tamże, s. 12. Por. Kiryk, Dzieje Buska, s. 23.

${ }^{63}$ ANI, G 6, s. 12. Por. tab. 3.

${ }^{64}$ Tamże, s. 109-110.
} 


\begin{tabular}{|c|c|c|c|c|}
\hline \multirow[b]{2}{*}{4.} & \multirow[b]{2}{*}{ Ołtarz św. Tekli } & $\begin{array}{l}\text { Msze św. czytane } \\
\text { suchedniowe }\end{array}$ & 4 razy w roku & cech szynkowy \\
\hline & & Msza św. czytana & raz w roku & $\begin{array}{l}\text { za duszę Wojciecha } \\
\text { Stachowicza, lokował } 100 \text { zł dla } \\
\text { cechu szynkowego }\end{array}$ \\
\hline \multirow{4}{*}{5.} & \multirow{4}{*}{ Ołtarz Różańcowy } & wotywy śpiewane & w soboty & Bractwo Różańcowe \\
\hline & & wotywy śpiewane & b.d. & Bractwo Literackie \\
\hline & & Msza św. rekwialna & raz w miesiącu & $\begin{array}{l}\text { za braci i siostry i fundatorów } \\
\text { Bractwa Różańcowego }\end{array}$ \\
\hline & & Msza św. rekwialna & raz w roku & $\begin{array}{l}\text { za duszę Wojciecha } \\
\text { Stachowicza }\end{array}$ \\
\hline \multirow{4}{*}{6.} & \multirow{4}{*}{$\begin{array}{l}\text { Ołtarz św. Anny } \\
\text { (bracki) }\end{array}$} & wotywa & we wtorki & $\begin{array}{l}\text { za braci i siostry z Bractwa św. } \\
\text { Anny }\end{array}$ \\
\hline & & Msze św. suchedniowe & 4 razy w roku & Bractwo św. Anny \\
\hline & & Msza św. & raz w roku & $\begin{array}{l}\text { za duszę Wojciecha } \\
\text { Stachowicza }\end{array}$ \\
\hline & & $\begin{array}{l}\text { koronka o św. Annie } \\
\text { śpiewana }\end{array}$ & $\begin{array}{l}\text { we wtorek } \\
\text { świąteczny ? } \\
\text { i w dzień św. Anny }\end{array}$ & $\begin{array}{l}\text { z pobożności śpiewa kapłan } \\
\text { z ludźmi }\end{array}$ \\
\hline \multirow{3}{*}{7.} & \multirow{3}{*}{$\begin{array}{l}\text { Ołtarz Opieki } \\
\text { Najświętszej Panny } \\
\text { Maryi }\end{array}$} & Msza św. czytana & w czwartki & za fundatorów \\
\hline & & wotywa śpiewana & w dzień opieki NMP & za fundatorów \\
\hline & & $\begin{array}{l}\text { Msza św. rekwialna } \\
\text { śpiewana }\end{array}$ & $\begin{array}{l}\text { w następnym dniu } \\
\text { po dniu Opieki NMP }\end{array}$ & $\begin{array}{l}\text { za duszę Stanisława i Reginy } \\
\text { fundatorów ołtarza }\end{array}$ \\
\hline 8. & Ołtarz św. Barbary & Msze św. & 12 razy w roku & $\begin{array}{l}\text { za duszę Jana Krolewskiego } \\
\text { dziedzica wsi Owczar }\end{array}$ \\
\hline
\end{tabular}

Źródło: ANI, G 6, s. 11-13.

Wśród odprawianych Mszy św. możemy wyróżnić odprawiane za fundatorów kościoła, klasztoru czy danego ołtarza, następnie wspomniane już Msze św. brackie, dalej za członków cechów działających w mieście i za innych dobrodziejów. Zauważa się też podział na Msze św. śpiewane i czytane, suchedniowe i rekwialne oraz wotywy.

Za fundatorów kościoła i klasztoru modlono się raz w tygodniu podczas Mszy św. przy ołtarzu głównym.

Do ołtarza św. Jadwigi przypisany był legat uczyniony w Krakowie w 1646 roku przez wdowę o nazwisku Pakoszowa, która darowała norbertankom buskim ziemię wraz z folwarkiem w zamian za cztery Msze św. w ciągu roku przy tym ołtarzu w intencji swojej duszy ${ }^{65}$.

Warto wspomnieć, również o zapisie Reginy Zawadzkiej wdowy, mieszczki buskiej, która w połowie XVIII wieku ofiarowała klasztorowi norbertanek 3 tys. zł na odnowienie stada bydła, które padło wskutek epidemii. W zamian zobowiązała klasztor do cotygodniowej Mszy św. za duszę jej i męża Stanisława oraz raz w roku Mszy św. rekwialnej i wotywy. Na altarię ufundowanego ołtarza Opieki Najświętszej Maryi Panny zapisała mały folwark z gruntami doń przylegającymi

${ }^{65}$ Tamże, s. 11. 
oraz sumę 20 zł 15 gr rocznie pochodzącą z kapitałów. Fundacja ołtarza została zatwierdzona przez biskupa Załuskiego ${ }^{66}$.

Wśród dobrodziejów należy też wymienić dziedzica wsi Owczary Jana Krolewskiego, który darował klasztorowi grunt w Busku wraz z łąką na opalanie lampki wiecznej przed Najświętszym Sakramentem. Fundacja ta była cały czas utrzymywana, ponieważ jednak dochody uzyskiwane z donacji były zbyt małe zakonnice $z$ własnych funduszy dopłacały na jej utrzymanie ${ }^{67}$. Za spokój jego duszy przed ołtarzem św. Barbary sprawowano w ciągu roku 12 Mszy św. ${ }^{68}$

W związku z legatami na rzecz klasztoru norbertanki ponosiły corocznie wydatki wynikające z poczynionych obligacji, wykaz ich z roku wizytacji znajduje się w poniższej tabeli $\mathrm{nr} 4$.

Tabela 4. Obligacje klasztorne w 1782 roku

\begin{tabular}{|c|c|c|}
\hline Rodzaj zobowiązania & Częstotliwość & $\begin{array}{c}\text { Wydatek w zł/intencja/inne } \\
\text { informacje }\end{array}$ \\
\hline Msze św. różańcowe śpiewane & raz w miesiącu & $36 \mathrm{zł}$ rocznie \\
\hline \multirow{7}{*}{ Msze św. } & \multirow[t]{2}{*}{ w czwartki przy ołtarzu Opieki NMP } & 84 zł „,kommendarzowi” \\
\hline & & $12 \mathrm{zl}$, ,szkolnym” \\
\hline & $\begin{array}{l}12 \text { razy w roku przy ołtarzu św. } \\
\text { Barbary }\end{array}$ & $12 \mathrm{zł} \mathrm{rocznie}$ \\
\hline & na św. Kajetana & \multirow[t]{3}{*}{ wynajęcie i opłacenie kapłana } \\
\hline & na święto Serca Pana Jezusowego & \\
\hline & od 1 do 3 tygodniowo & \\
\hline & w poniedziałki & za dobrodziejów \\
\hline $\begin{array}{l}\text { Godzinki o Niepokalanym } \\
\text { Poczęciu NMP }\end{array}$ & w poniedziałki i soboty & $28 \mathrm{zl}$, ,szkolnym" \\
\hline Różaniec śpiewany & $\begin{array}{l}\text { w niedziele, środy, piątki i w każde } \\
\text { święto }\end{array}$ & 12 zł rocznie zakrystianinowi \\
\hline Pacierze & co tydzień po pięć za dobrodziejów & wynajęcie i opłacenie kapłana \\
\hline \multirow{7}{*}{ Officium Defunctorium } & \multirow{3}{*}{4 razy w roku } & za Jana Krolewskiego \\
\hline & & $\begin{array}{l}\text { za Kantego i Zuzannę Koczowskich, } \\
\text { którzy dali } 7 \text { tys. na wykup } \\
\text { Kliczanowa od dzierżawcy } \\
\end{array}$ \\
\hline & & $\begin{array}{l}\text { za Michała i Aleksandrę } \\
\text { Misiowskich, którzy dali } 3 \text { tys. na } \\
\text { prowizję }\end{array}$ \\
\hline & raz w roku & za dobrodziejów \\
\hline & na św. Trójcę & \\
\hline & na św. Grzegorza & \\
\hline & w Dzień Zaduszny & \\
\hline
\end{tabular}

Źródła: ANI, G 6, s. 15-16.

${ }^{66}$ Tamże, s. 13-14. Prowizje od ołtarza Opieki NMP-, ,u Damazynowy od kapitału złł 1005 na rok”, „, Od Jakuba Kowalskiego od kapitału złł. 100 czynszu złł 5”, „Od Żółtaka od kapitału złł 50 czynszu złł 2 gr. 15”, „W Jmci P. z Nestorowiczów Rucka płaci corocznie złł 18 z testamentu śp. Zawadzkiey”.

${ }^{67}$ Tamże, s. 14-15.

${ }^{68}$ Tamże, s. 14. 
Z zestawienia wynika, że zobowiązania konwentu wobec donatorów były liczne. W ciągu roku było to od 130 do 240 Mszy św., 16 Mszy św. żałobnych, około 250 pacierzy za dobrodziejów, 180 śpiewanych różańców i 12 Mszy św. różańcowych, przeszło 100 razy odmawiane godzinki. Nie mamy danych na temat kosztów związanych z odprawianiem tych nabożeństw, ale wydaje się, że były one znaczne. Należało opłacić kapłanów, służbę kościelną i uczniów szkoły parafialnej.

Warto nadmienić, że do czasu I rozbioru zakonnice zamawiały Officium Defunctorum za Władysława Jagiełłę i Jadwigę z racji uzyskanego od króla przywileju na sól bocheńską. Jednak z powodu utraty Bochni i Wieliczki na rzecz Austrii przywilej ustał a dotychczasowa intencja była zamieniona, nazwana została „za dobrodziejów" i była sprawowana jak poprzednia raz w roku ${ }^{69}$.

Ale życie mieszkańców koncentrowało się nie tylko wokół spraw religijnych, którym ton nadawał klasztor norbertanek. Protokół wizytacyjny zawiera też wzmianki na temat uregulowań prawnych i stanu gospodarki miejskiej.

W Busku w 1782 roku istniały cztery cechy rzemieślnicze: szewski, piekarski, krawiecki i szynkowy. Pierwszy z nich zatwierdzony został w 1490 roku przez kardynała Fryderyka Jagiellończyka, a temat powstania kolejnych nie posiadamy żadnych wzmianek. Możemy jedynie domniemywać, że istnienie w Busku w 1571 roku 41 a w 1579 roku już 81 rzemieślników oraz 13 gorzelników przyczyniło się do powstania w tym czasie cechów rzemieślniczych ${ }^{70}$.

Nie znamy ani liczby członków poszczególnych cechów, ani wysokości opłacanych przez nich składek. Wizytator jedynie przypominał o konieczności corocznego rozliczania się z posiadanych funduszy przed komisją złożoną z komisarza klasztoru, starosty i wójta. Mieli oni dokonać przeglądu i zatwierdzenia rachunków, ,aby próżnych wydatków ile na pijaństwa po sessyach nie czynili”71. Wydatki cechowe obejmowały powinności wobec kościoła, związane z opłaceniem światła na ołtarzach. I tak cech szewski opalał ołtarz wielki, co może świadczyć o jego znaczeniu w przeszłości i fakcie pojawienia się go jako pierwszego na terenie Buska. Ale wydaje się, że znaczenie cechu szewskiego w II połowie XVIII wieku było mniejsze, ponieważ wizytator podkreślał, że jego członkowie fundują tylko parę świec. Powinnością cechu piekarskiego było opalanie ołtarza św. Norberta, krawieckiego św. Jadwigi a szynkowego św. Teklii². Ponadto każdy z cechów zamawiał Msze św. i modlitwy za członków, zarówno żyjących jak i zmarłych. Odprawiane były przy tym ołtarzu, na który fundowano światło. Cech szewski opłacał pięć Mszy śpiewanych rocznie przy wielkim ołtarzu, cech krawiecki także pięć, ale czytanych przy ołtarzu św. Jadwigi, po cztery Msze św. czytane rocznie zamawiali członkowie cechu piekarskiego przy ołtarzu św. Norberta i cechu szynkowego przy ołtarzu św. Tekli ${ }^{73}$. Druga grupa wydatków ce-

\footnotetext{
${ }^{69}$ Tamże, s. 15. Por. Guldon, Stępkowski, Busko na tle miast, s. 32-33.

${ }^{70}$ Kiryk, Dzieje Buska, s. 13; Kiryk, Urbanizacja Małopolski, s. 30.

${ }^{71}$ ANI, G 6, s. 121.

72 Tamże, s. 14.

${ }^{73}$ Tamże, s. 11-12. Por. tab. 3.
} 
chowych dotyczyła powinności wobec miasta i cechu i określone zostało, że „do [s]karbony mieyskiey przykładać się y cechowey" powinni ${ }^{74}$.

Z protokołu wizytacyjnego wynika, że mieszczanie w Busku byli ubodzy, zajmowali się drobną wytwórczością rzemieślniczą i „w mieście nie masz żadnego z mieszczan tak dostatniego, aby mógł handlować suknem, materyami przynaymniey ostremi i korzeniami a klasztor, liczni parafianie nad to dystyngowani tego potrzebują"75. Brakowało też rękodzielników z zakresu złotnictwa czy kuśnierstwa a działający określeni zostali jako „partacze, nietrzeźwi, zawodni”76.

Podkreślić należy, że głównym źródłem utrzymania mieszkańców w tym okresie, podobnie jak w wielu innych miasteczkach regionu było rolnictwo. Wspomina o tym zresztą wcześniej wzmiankowany J.F. Carosi pisząc: „Głównym środkiem utrzymania jest rolnictwo oraz plantacje anyżu, którego zbiera się tu rocznie w tej okolicy kilkaset korcy [...]. Skupują go Żydzi, rozprowadzając go następnie po gorzelniach wódki w kraju" 77 .

Ponieważ w Busku istniał zakaz osiedlania się Żydów, wizytator z powodu braku innych pomysłów na ożywienie gospodarki pozwolił na sprowadzenie i osiedlenie w graniczącym z miastem Nadolu kilku Starozakonnych kupców i rzemieślników. Uważał, iż może to przyczynić się do aktywności gospodarczej w miasteczku i okolicach oraz umożliwi szybkie zaopatrzenie w potrzebne towary ${ }^{78}$.

Szansę taką stwarzało również odkrycie i eksploatacja złóż soli w okolicach Buska i w samym mieście. W 1783 roku Karl Leopold von Beust rozpoczął poszukiwania a już w następnym roku norbertanki wydzierżawiły grunty pod budowę szybów służących do jej wydobycia. Okazało się, że pokłady soli były niewielkie, stąd i produkcję prowadzono na małą skalę. Dostępność do złóż solnych w Bochni i Wieliczce po III rozbiorze stała się z czasem przyczyną całkowitego zaniechania eksploatacji. Podjęte więc na tym polu działania nie stały się powodem ożywienia gospodarczego ${ }^{79}$.

O regresie gospodarczym świadczył też brak w mieście młyna, wiatraka i karczmy. Zalecenia w związku z tym były następujące: norbertanki powinny wybudować wiatrak, karczmę dla podróżnych przy drodze na Chmielnik, poza

${ }^{74}$ ANI, G 6, s. 122.

${ }^{75}$ Tamże, s. 124.

${ }^{76}$ Tamże.

${ }^{77}$ Carosi, Reisen durch verschidene, s. 217, 218 za: Guldon, Stępkowski, Busko na tle miast, s. $30-31$.

${ }^{78}$ ANI, G 6, s. 124-125. „Przeto pozwalamy Wielebnemu Zgromadzeniu, aby do wioski Nadola, łączącej się z miastem, sprowadzili i osadzili kilku kupców niewiernych, bo w mieście samym ani na żadnym placu i gruncie miejskim nie dozwalamy mieć Żydów osiadłych i mieszkających, którzy wszelkie mogliby mieć towary, a dostawianiem ich czynili wygodę miejscu i okolicy. Rzemieślników także jakich nie masz w mieście, jako to: złotników, kuśnierzów i innych wolno osadzać w zmiankowanej wiosce Nadolu, przez co przyczyni się intraty a pomoże wielkim niedostatkom, którym zapobieżać nie wynajdujemy innych sposobów".

${ }^{79}$ Guldon, Stępkowski, Busko na tle miast, s. 34-35. O zainteresowniu króla Stanisława Augusta Poniatowskiego rozwojem wydobycia i produkcji soli świadczy pobyt w Busku w dniu 12 VI 1787 r., gdy „Wyszedłszy z kościoła pojechał do fabryki solnej, tam tak oficjalistów, jako też i pracujących wedle tej fabryki, udarował dukatami”. Por. ANI, G 5, s. 7. 
obszarem miejskim oraz ratusz, gdzie część pomieszczeń miała pełnić rolę zajazdu z wyszynkiem dla interesantów, kupców i samych mieszczan. Wszystkie te przedsięwzięcia miały ożywić miasteczko a oddanie ich w arendę mogłoby przysporzyć zysków również i samym mieszczanom.

Do powinności mieszkańców należało uiszczanie podatków, świadczenie wszelkich powinności związanych z posiadaniem gruntów oraz dbałość o utrzymanie przejezdności dróg prowadzących do miasta i w jego granicach poprzez niwelowanie dołów, zasypywanie ich kamieniami i wyrównywanie. Wszelkie sprawy sporne rozstrzygane były przez wójta i burmistrzów, mieszczanie mieli prawo wnosić apelację do starosty buskiego, kolejną instancją był komisarz klasztoru a decyzja władzy diecezjalnej była ostateczna ${ }^{80}$.

Mieszkańcy Buska mieli zagwarantowane od niepamiętnych czasów prawo do wytwarzania gorzałki. Przywilej nadany był przez proboszczów i określał dozwoloną ilość produkowanej we własnych domach gorzałki, miało to zaspokajać ich potrzeby lub ewentualnie dopuszczana była jej sprzedaż poza granicami państwa. Zabronione było jednak szynkowanie win i miodów bez zgody klasztoru oraz sprowadzanie wszelkich alkoholi.

Mieszczan obowiązywał zakaz wydzierżawiania, sprzedawania i zastawiania majątków szlachcie, za takie poczynania groziła kara konfiskaty dóbr i wygnania. Zasady powyższe obowiązywały w związku z trudnościami w odzyskaniu dóbr $z$ rąk szlachty. $Z$ dokumentu widać, iż w poprzednich latach istniały zapewne problemy tego rodzaju i właścicielki miasta chciały w przyszłości uniknąć podobnych problemów. Aby również w inny sposób dobra mieszczan nie stały się własnością szlachecką obowiązywał całkowity zakaz zawierania małżeństw mieszczanek buskich z kandydatami stanu szlacheckiego. Jedynym warunkiem umożliwiającym zawarcie takiego związku było sprzedanie przez wdowę majątku innemu mieszczaninowi, wypłacenie córce posagu w gotówce i prawne zrzeczenie się przez nią sukcesji do majątku ${ }^{81}$.

Wszyscy zbiegli mieszczanie mieli być odstawiani do miasta a o ich dalszych losach decydowały zakonnice, podobnie jak i o wielu innych sprawach dotyczących organizacyjnych i prawnych uregulowań obowiązujących w mieście.

Reasumując, należy stwierdzić, że w latach osiemdziesiątych XVIII stulecia Busko należało miasteczek, w których mocno zarysowywał się regres gospodarczy, a mieszkańcy utrzymywali się przede wszystkim z rolnictwa. O zubożeniu ludności świadczy drewniana zabudowa miasta, brak rzemieślników, zanikanie tradycji handlu. Dostrzega się próby ożywienia gospodarczego poprzez osiedlenie w okolicach miasta rzemieślników i kupców żydowskich czy próby eksploatacji niewielkich złóż soli. Zwraca się też uwagę na konieczność edukacji młodzieży, co dobitnie uwidoczniło się w inicjatywie reaktywowania dobrze prosperującej szkoły parafialnej i poparciu idei prowadzenia pensji klasztornej w zgodności z potrzebami kształcenia dziewcząt $m$.in. w zakresie nauczania języków obcych.

\footnotetext{
${ }^{80}$ ANI, G 6, s. 120, 124.

${ }^{81}$ Tamże, s. 120 - 121.
} 
W Busku, mieście należącym do grupy miast prywatnych miasteczek stanowiących własność duchownych, życie mieszkańców koncentrowało się wokół kościoła parafialnego, o czym świadczy dbałość zarówno parafian jak i norbertanek o jego wystrój, wyposażenie oraz właściwe sprawowanie liturgii.

\section{ANEKS}

\section{Tekst 1. Wyposażenie kościoła ANI, G 6, s. 23-34.}

\section{Srebro}

- kielich srebrny w środku i z wierzchu z pateną wyzłocony, na wierzchu kielicha floresy i obwódka srebrna

- kielich cały srebrny, wewnątrz wyzłocony z pateną srebrną pozłoconą

- krzyż srebrny dęty, korpus wyzłocony, na nim insygnia SS. Ewangelistów srebrne wyzłacane, a na drugiej stronie za szkłem Agnus Dei, gwiazdeczek wyzłoconych z kamykami czeskimi cztery na dwóch rogach, pod śrubami sztuczki wyzłacane

- Vascula na olej święty srebrne na jednym sedesiku puszeczek z przykrywadełkami trzy, na których gałeczek z krzyżykami wyzłacanymi trzy, po tych obrączek wyzłacanych osiem, te vascula w środku wyzłacane

- puszek małych srebrnych na olej S. do chorych 2

- puszka mała srebrna, do chorych

- patena mała srebrna z przykryciem cała wyzłacana, do chorych

- taca mała srebrna pod ampułki bez pozłoty

- ampułki srebrne małe dwie z tych jedna na środku wyzłacana z przykryciem

- trybularz o 4 łańcuszkach srebrny;

- srebrna łódka z przykryciem i łyżeczką

- para małych lichtarzy srebrnych

- korony na obrazach MB srebrne pozłacane 4 szt., dwie z nich wysadzane kamykami czeskimi

- mała korona srebrna na głowie MB w ołtarzu z czeskimi kamykami

- korona mała w promienie, palma i krzyżyk srebrny wyzłacane w obrazie św. Tekli

- dwie infuły z pastorałem, krzyżem monstrancją i sercem srebrne szt. 6

- świat w jabłkosrebrny pozłocisty

- maleńki krzyżyk i berło na obrazie MB Różańcowej

- wota srebrne w tabliczkach szt. 20

- wota srebrne w serca szt. 8

- wota srebrne maleńkie szt. 4 
- kokarda srebrna z czeskimi kamykami szt. 1

- sztuczki srebrne na lasce od osuwania firanek z widełkami szt. 20

- perły - kokarda z prawdziwych perełek na wstążce 1 szt.

- perły drobne prawdziwe sznury krótkie $10 \mathrm{szt}$.

- korale - na obrazie MB w ołtarzu wielkim 30 szt., na obrazie MB Róż. 18 sznurków, na obrazie MB Opieki sznurków 18, na obrazie S. Teki sznurków 15, na obrazie S. Anny i NMP sznurków 28

Mosiądz

- para lichtarzy większych i mniejszych;

- trybularz o 4 łańcuszkach

- lódka zawierana

- świecznik czyli rogacz wiszący na łańcuchu żelaznym przed wielkim ołtarzem na nim pod świece 2 lichtarze

- lampa mała wisząca przed różańcem

- promienie mosiężne wyzłacane wiszące nad głową Chrystusa pod sklepieniem

- małe dzwonki do Mszy 2 szt.

- dzwonek przy zakrystii metalowy

- dzwoneczki metalowe do Mszy 4 szt.

- para waltorni chórowych

- trąby dobre 3 szt. i 1 popsuta

- dzwoneczek mały do Mszy 1 szt.

— żelazka do prasowania bielizny 2 z żelaznymi duszami

- Miedź

- kociołek na wodę święconą,

- wanna w chrzcielnicy wybielana

- sukienka na ołtarzu wielkim miedziana posrebrzana i w części pozłacana

- sukienka na obrazie różańcowym posrebrzana i w części pozłacana

- sukienka na obrazie Opieki NP posrebrzana i w części pozłacana

- sukienki na obrazach św. Augustyna i św. Norberta posrebrzane 2 szt.

- kotły chórowe para

_ stolik do suszenia korporałów z żelaznymi prętami

Cyna

- lawaterz w zakrystii z nalewką i tacą

- lichtarze większe 6 par mniejsze 9 par

- krzyż na procesje

- naczynia na oleje św.

- tacka do chrzcielnicy

- łyżeczka do łódki z mosiądzu 
Blacha biała

- lampy posrebrzane wiszące 2 szt.

- pudełko na Hostię

- latarnia z dwoma drzwiczkami ręczna

- Żelazo

- kociołki do trybularzy 2 szt.

- żelaza do pieczenia opłatków 2 szt.

- pręt do wieszania opon nad wielkim ołtarzem

- szczypce, cyrkuły do wyrabiania komunikantów 2 szt.

Kamień

- Chrzcielnica z kamienia nowo wyrobiona na postumencie kamiennym $\mathrm{z}$ wierzchem drewniany w koronę snycerską robotą nowym jeszcze nie malowanym, pręt żelazny ze skoblem do zamykania

- Szkło

- zwierciadła szlifowane duże 7 szt., mniejsze proste 2

- lustra szklane - zwierciadła 2, cienie szklane 32

- ampułki kryształowe 3 pary

- ampułki proste 4 pary

Drewno

- sukienki na obrazach złotem i srebrem malowane 4 szt.

- pacyfikał w promienie w tym drzewa Krzyża S. i 12 Apostołów za szkłem częściowo pozłacane i posrebrzane są te relikwie

- relikwiarze w ołtarzu wielkim snycerską robotą złotem malarskim wyzłocone 4 szt.

- trumienki na niebiesko malowane snycerską robotą 2 szt.

- lichtarze większe i mniejsze 9 par

- grób na Wielki Piątek malowany na deskach z hakami i skoblami żelaznymi

- piramidy pod lampy malowane 5 szt.

- mensa w zakrystii i pod nią szuflady 8 szt.

- krzesło, taboreciki 2, suknem czerwonym obite

- katafalk z 3 gradusami i stara trumna

- konfesjonały 5 szt.

Aparaty

- białe bogate - ornat srebrny, na dnie złotem w osoby i kwiaty haftowany, galonem złotym szamerowany, kitajką w płomienie podszyty, ze stułą i manipularzem, welum, palą i bursą 
- ornat na lamie białej w kwiaty złote $\mathrm{i}$ jedwabne różnego koloru kolbertyną złotą szamerowany, kitajka niebieska niedawno sprowadzony, do niego 2 dalmatyki ze srebrem

- ornat na białej roi w palecie złote hafty

- ornaty na białym atłasie 2 szt. na białym adamaszku; jeszcze 3 inne białe, bogate

- białe powszechniejsze -4 szt.

- kapy białe 3 szt. i białe powszechniejsze 3 szt.

- antepedia 9 szt.

\title{
BUSKO IN LIGHT OF THE DESCRIPTION OF BISHOP MICHAL JERZY PONIATOWSKI'S VISITATION OF 1782
}

\begin{abstract}
Summary
The article is based on the description of the visitation of 1782 held in the convent of Norbertine Sisters in Busko. This description is placed in the manuscript book entitled „The act of the general visitation...". The manuscript, including 130 pages of text, is an extremely valuable source of information on the town owned by the nuns and the convent of the Norbertine Sisters.

This manuscript helps to recreate the appearance of Busko in this period, its urban character, the appearance and equipment of the church dedicated to Immaculate Conception of the Holy Mary (it was also a parish and a monastic church), wooden Church of St Leonard, the convent and the buildings forming part of the monastic grange. It is also possible to gain information on the financial status of the nuns in the context of their salaries and the financial and economic problems. Wooden buildings, the falling number of craftsmen and the disappearance of trade traditions confirm the deteriorating economic condition of the convent. In the post-visitation recommendations, we find points relating to the necessity of the settlement of Jewish merchants and artisans in the vicinity of Busko. These observations demonstrate the ways to recover the town economy indicated by the bishop.The most valuable thing, however, seems to be the opportunity to learn about the inner structure of the convent at that time, people who were part of the convent, functions performed by the nuns, the organization of the inner life, nun spirituality and the nunnery-town relations. On the pages of the manuscript we find the mention of the nunnery and the parish school, the hospital for the poor, the urban guilds and their participation in religious life, brotherhoods, and the privileges and responsibilities of burghers to the owners of the town and vice versa.

This source is even more valuable because of the fact that the urban books of Busko did not survive and the materials about the Norbertine convent are in a fragmentary state.
\end{abstract}

